\title{
Measuring the Essence of Local Wisdom's value in the Behavior of Government Apparatuses in State Administration Institutions
}

\author{
Mohamad Ichsana Nur*, Reni Qurroti Aeni \& Tedi Juana \\ Public Administration Department, Faculty of Social science and Political Science, \\ Universitas Islam Negeri Sunan Gunung Djati Bandung, Indonesia
}

Received: August 07, 2021; Reviewed: August 07, 2021; Accepted: September 08, 2021

*Corresponding Email: mohamadichsana22@uinsgd.ac.id

\begin{abstract}
This research aimed to examine how local wisdom's value was applied to government reform at the State Administration Institute (LAN) in Jatinangor, West Java. This study focuses on restructuring the government apparatus so that it can apply national ideals derived from the community in which it lives. This study uses a qualitative approach with a descriptive type of research. The data was obtained using the purposive sampling technique. This research shows that the State Administration Institution as an institution requires the right values. Must adopt these values to the area's cultural values and character, where the Jatinangor State Administration Institute (Puslatbang PKASN) has the value of local wisdom called SAHATE. The application of SAHATE as the value of local wisdom positively impacts the organizational climate of LAN Jatinangor. The application of these local values has a positive influence on the work environment. Namely, each employee is very concerned about the relationship between individuals. It can suppress individual and sectoral egos so that all employees can focus on organizational goals and not focus on individual or group interests.
\end{abstract}

Keywords: Bureaucratic Reform; Local Government; Local wisdom; Organizational Climate

How to Cite: Nur, M.I. Aeni, R.Q. \& Juana, T. (2021). Measuring the Essence of Local Wisdom's value in the Behavior of Government Apparatuses in State Administration Institutions. Jurnal Administrasi Publik (Public Administration Journal). 11 (2): 161-168 


\section{INTRODUCTION}

Globalization

has compelled

governments in all countries to continue to adapt to the advancement and development of the times. In Indonesia, various modifications and adjustments have happened, including those in 1998 and eventually became known as bureaucratic Reform. A purposeful endeavor to make a complete and comprehensive change to areas of Government, including to modernize governance, is known as bureaucratic Reform (Prasojo \& Kurniawan, 2010). Tjahjo Kumolo, as quoted in (Kementerian Pendayagunaan Aparatur Negara dan Reformasi Birokrasi, 2020), mentions that there are three main things or elements that are a concern for bureaucratic Reform, which includes structure, human resources, and institutions.

In supporting reform efforts with these three elements, public agencies need several systems in their implementation (Jackley, 2008). The system is generally absorbed from western values, which have become the core study of public administration and bureaucracy since its emergence in Indonesia. However (B. Saputra et al., 2018), The author claims that Western principles have failed to give developing countries, particularly Indonesia, an ideal bureaucratic system. Compared to values derived from other regions or nations, these local values provide a complete vision of life (Hart, 2010).

In 2019, based on the results of a survey conducted by The World Bank quoted in (theglobaleconomy.com, 2020), The efficacy of the Indonesian Government is ranked fifth out of eleven Southeast Asian countries. The information comes from reviewing numerous factors, including the Government's quality of services, policy development quality, and policy execution quality. Can find more information on the value of government effectiveness in Southeast Asian countries here:

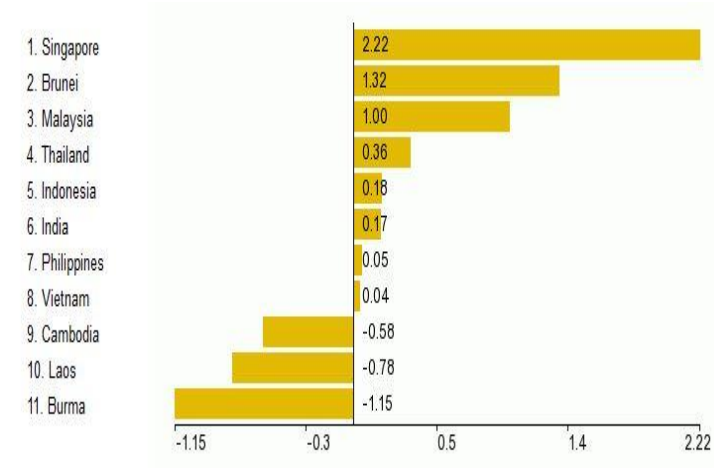

Figure 1. Southeast Asia Government Effectiveness Ranks and Scores in 2019

Source: The World Bank in (theglobaleconomy.com, 2020)

By being ranked 5th for the effectiveness of Government carried out by Indonesia, the Government still has to make basic improvements, especially by maximizing the concept of local indigenous or local wisdom for optimal achievement of bureaucratic Reform. This is linear with research conducted by (Jumiati \& Saputra, 2019) which states that in solving complex and complicated public administration problems, one of the solutions offered is a public administration model based on local wisdom, where administration depends adapted to the administration being operated.

The Government's position as a policymaker is crucial, especially when setting the anticipated quality of human resources (Anggara et al., 2018). Because the Government can mobilize the community, it plays a crucial role in the development of current human resources (Saputra et al., 2020). Developments that occur require ASN in Indonesia to be progressive in creating innovations to answer the challenges for improving human resources in Indonesia. As stated in (Zulfah 2013), the existing human resources can determine the country's progress.

Every Indonesian ASN must be progressive in creating innovations to answer the challenges that exist for improving human resources in Indonesia. The Jatinangor State Administration 
Institute (Puslatbang PKASN) is a government institution that is the leading public agency sector in Indonesia; the organizational climate built in its work environment needs to be adapted to local wisdom to create reliable, resilient, and mutually embracing human resources.

This institution applies the value of SAHATE's local wisdom in creating a friendly and comfortable organizational climate or public environment. In 2017 the Jatinangor State Administration Institute (Puslatbang PKASN) received various achievements such as ranking the satker with the best budget execution performance, the third rank in 2016 budget management performance in the LAN RI environment; Puslatbang researchers successfully presented scientific papers at the international level in 2017.

In addition, based on the 2016 performance report, the Jatinangor State Administration Institute (Puslatbang PKASN) received a score of 8.3 for the satisfaction index of training at the Jatinangor PKASN Puslatbang State Administration Institute. Furthermore, this agency also received an award as the best service innovation, which indicates that human resources at the Jatinangor State Administration Institute (Puslatbang PKASN) can provide public services so that the agency's performance can be proven by the achievements obtained. This is inseparable from local wisdom (SAHATE), which is absorbed as the basis for HR behavior within the Jatinangor State Administration Institute (Puslatbang PKASN) itself.

According to previous interviews and observations with Mr. Hari Nugraha, S.E., MPM, the Head of the PKASNN LAN RI Center for Research and Development, some of the accomplishments were aided by the application of the SAHATE value that has been assigned to each ASN in the PKASN Center for Research and Development. This is because the SAHATE value will form the character of ASN at the PKASN Center for Research and Development to work together with heart and decrease sectoral egos between disciplines. In other words, we can use the performance of the existing ASN to determine the success of implementing the SAHATE value.

As a result, bureaucratic Reform can only be considered a success if it improves service quality while also establishing a clean and accountable government. In this case, however, the Jatinangor State Administration Institute (Puslatbang PKASN) has succeeded in reforming the bureaucracy, particularly its human resources, by incorporating local expertise, as evidenced by the receipt of multiple prizes. As a result, Puslatbang PKASN Jatinangor's concept of local wisdom can be used as a best practice from attempts to realize the vision of bureaucratic Reform.

According to (Kementerian PAN-RB, 2018), Bureaucratic Reform is the key to answering the public's dissatisfaction with the services provided by the Government, where the purpose of the bureaucratic reform effort is to create a clean and accountable government and has better services. One of the goals of bureaucratic Reform is to make the bureaucracy an effective institution in mediating narrow political processes and broad public interests. One way to maximize bureaucratic reform efforts, as said (Jumiati \& Saputra, 2019), is to apply the concept of local wisdom in governance, which is referred to as the concept of Indigenous Public Administration (IPA).

Local Indigenous according to (B. Saputra et al., 2018) In principle, it is a concept that is created to fill the hole left by western-style public administration, and it emerges spontaneously to fill that void. Indigenous Public Administration (IPA) is categorized into three types based on when they were born: 1) IPA before the colonial era; 2) IPA during the colonial era; 3) IPA after the colonial era. 
Local indigenous are closely related to indigenous people. The community has the independence to become someone who can determine everything by himself and has the legitimacy to regulate himself and all the resources in his environment. (Cruz et al., 2020).

This will certainly help the local Government to be able to communicate with the community regarding development programs (Burford et al., 2013), or in other terms will create co-management and shared administration practices for the management of the area's natural resources (Johnson et al., 2016).

In addition, this local indigenous is also related to indigenous knowledge, where each community has unique knowledge, very deep understanding, and distinctive beliefs and habits (Tanyanyiwa \& Chikwanha, 2011). As a result, an effective governance system necessitates a dynamic process, interaction, and structure. Certain community groups or communities organize themselves collectively to achieve something useful and expected (Basheka, 2015).

Many studies have examined the application of local values, such as those carried out by (Efendi, 2014) which examines the implementation of cultural values carried out by the Ciamis City Indigenous Village community, which is used as teaching material for Social Sciences (IPS) subjects. The results of his research explain that there are many values of local wisdom that can be used as teachings, such as the values of cooperation, responsibility, and good manners.

Riley \& Johansen (2019) argued that the issue of local values in the world of public administration received considerable attention. For example, in the management of natural resources of an area, that culturally needs to be considered by how the local population lives their lives. So the local Government is asked to learn and not interfere with their lives so that the
Government can design better and more appropriate development programs.

Other research was also conducted by (Hikmah et al., 2020), who got the results that the auction of milkfish as a local indigenous has religious, social, and economic values so that it has an influence on the economic growth of the Sidoarjo community through the Government which has the authority and acts as a drafter so that the Sidoarjo Regency Government will continue to implement and maintain the values and the milkfish auction.

The research conducted by the researcher is different from previous research conducted by several other academics, where the researcher focuses on best practices from the application of local values carried out by the Jatinangor PKASN Research Center. This research is important because this research will provide input to the Jatinangor PKASN Research Center in maximizing the values of local wisdom contained in the SAHATE program.

Based on the explanation above, researchers are interested in studying the value of SAHATE local wisdom in the Jatinangor State Administration Institute (Puslatbang PKASN) and testing how the application of SAHATE as a local indigenous in the State Administration Institute (Puslatbang PKASN) Jatinangor. The purpose of this research is to analyze the importance of implementing SAHATE as a local indigenous at the State Administration Institute (Puslatbang PKASN) Jatinangor so that the benefits to be achieved from this research are that it can contribute to the evaluation of program improvements and values that apply at the State Administration Agency ( Puslatbang PKASN) Jatinangor as well as being a reference for other agencies in using local wisdom values.

\section{RESEARCH METHODS}

This research was conducted using a descriptive qualitative method. The research process involved several 
questions and procedures intending to understand how to apply the SAHATE value as a local indigenous used as an organizational climate.

They researched at the State Administration Institute (Puslatbang PKASN) Jatinangor. In obtaining research data, researchers utilize primary and secondary data. Primary data is obtained directly from related agencies, namely the head of the Center for Development, Head of the Administration Unit, and Head of Human Resources for the Jatinangor Administrative Institute (Puslatbang PKASN).

The data collection technique is carried out by determining the sample that will be the source of data (purposive sampling). The data collection technique is the in-depth interview, where the researcher explores further the concepts, principles, and meaning of the value of local wisdom from related parties. All data that has been collected and then analyzed, according to Miles and Huberman, data analysis is carried out through three stages, namely, reduction, coding or data presentation, and concluding.

\section{RESULT AND DISCUSSION}

The Jatinangor State Administration Institute (Puslatbang PKASN) and other agencies, in general, require the correct values to build a good organizational climate for the accomplishment of highquality human resources. Must be tailored to these principles to the region's cultural values and identity. In general, LAN RI has a value called IPIP (Integration, Professional, Innovation, Caring) that is utilized as a guide and a code of ethics that all LAN agencies must follow. In addition to the IPIP value and code of ethics, the Jatinangor State Administration Center (Puslatbang PKASN) values SAHATE local wisdom, which is relevant to the agency's creation Sunda district in West Java.
This discussion will be divided into three categories: the essence of SAHATE, the application of SAHATE, and the impact of the SAHATE program.

\section{ESSENCE OF SAHATE}

SAHATE was established in 2015, according to data collected from the Central Head of the State Administration Agency (Puslatbang PKASN) Jatinangor, as a philosophical value developed from the local wisdom of the Sundanese culture. Polite, Harmonious, and Firm is an acronym for SAHATE. These ideals establish a shared work culture that emphasizes the need to assist one another. SAHATE is also derived from a Sundanese cultural value, "Sarendeuk Saigel Sabobot Sapihanaeun, Sabata Sarimbagan," which means "remain together and never fight if you have different viewpoints, get along and respect each other."This is because the relevant agencies have a vision of togetherness that is adapted to the local culture. This can be seen from the schematic below:

Sarendeuk, Saigel,

Sabobot, Sapihanaeun,

Sabata, Sarimbagan

(Tetap bersama dan

tidak bertengkar karena

berbeda pendapat, rukun

dan saling menghargai)

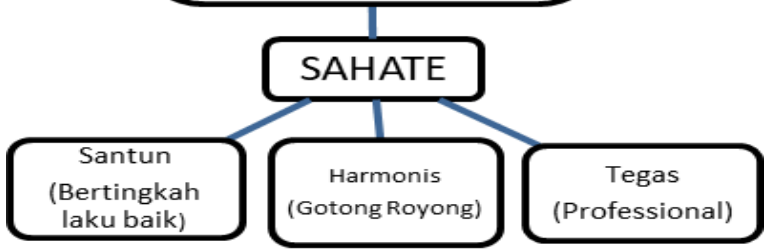

Figure 2. SAHATE Value Scheme

Source: Center for PKASN LAN Jatinagor, 2020

Can draw A common thread from the above scheme: the main base of the SAHATE value, which is used as the organizational climate at the Jatinangor State Administration Institute (Puslatbang PKASN), is highly respected local wisdom, so to preserve this value, SAHATE is appointed as a mutually agreed-upon guide in carrying out a job. The Jatinangor PKASN 
Development Center is located in the province of West Java. As a result, all personnel who come to work for this organization must share common ideals, even from various parts of the country.

SAHATE or Sehati shows the character of working together, being aware of each other, and caring for each other to create a "sense of home" work environment. Sundanese culture itself is very thick with kinship. Therefore this needs to be built and implemented. Linear also does not speak as if the office is separate from the individual vision and mission. However, part of the employee's vision and mission so that it becomes a part of oneself.

SAHATE aims to reduce each individual's ego, and the entire apparatus must recognize that some persons' success while ignoring others' failures is not a success. Although, in the end, the agency's performance will be regarded to be superior. This organization is divided into three sections: administration, research and development, and assessment. The value of local expertise will lessen the sectoral ego that each unit stands alone and all units have goals that must realize together.

SAHATE has a special logo as a symbol of the core values of the Center for Development and Development, namely a heart with five fingers, the fingers are analogous to an individual body, five fingers form a heart meaning together one goal. In general, SAHATE becomes the philosophical value of all actions in the work environment, which can create a culture of working together and helping each other. This can have a good impact on the performance of agencies in general because environmental comfort affects personal comfort at work.

\section{SAHATE APPLICATION}

The application of local wisdom values takes place in two ways: socialization and action. The introduction of SAHATE to every apparatus is linked to socializing. The natural form of socialization is supporting media that describes SAHATE, such as banners, clothing with the five-finger heart symbol, and mass media such as journals, websites, and social media. The apparatus will immediately realize that the Puslatbang work atmosphere values togetherness with this form of socializing. Where is it expected that this will result in helpful actions?

Meanwhile, the action method is embodied in informal programs, which can build family togetherness and harmony. These programs include sports with officials from all units; usually, each employee has their duties, so they rarely communicate, especially with employees from different units. However, the existence of joint sports opens up opportunities for employees to interact with all apparatus in the Puslatbang environment, not only for employees but all functional work units are also involved.

The second program is "chat together" (informal conversation activities). In general, management and employees have little or no opportunity to connect. During informal chats, colleagues can explain any hurdles or tell topics outside of the work setting, allowing the boss to learn about all of his employees' problems. A dinner frequently accompanies this program for all employees, which fosters a sense of community. This program is considered important because, as the results of research conducted by several researchers, including(Ardiansyah 2016), explain that communication is very influential on the performance of employees.

The next program is a family gathering; according to the head of the PKASN Puslatbang Administration unit, this program involves the family, this is because the family can affect the psyche or act as a "support system" for employee performance, so families need to be formed to support the work of employees in the office. With the family gathering, it is hoped that the family can understand the employee's work environment to understand the context of the work being carried out. In addition, to strengthen the emotional relationship between the family of one employee and the family of another 
employee. To facilitate understanding, the following is an explanation in the form of a schematic:

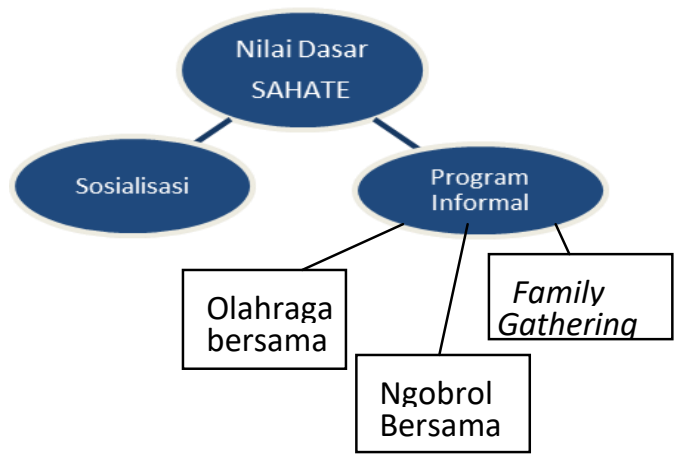

Figure 3. SAHATE Deployment Scheme Source: Center for PKASN LAN Jatinagor, 2020

From this scheme, it can be concluded that the basic values of SAHATE will be established as a result of the existence of several existing programs and that this will then serve as a trigger for an organizational culture that occurs continuously and periodically, thereby establishing the purpose of the existence of SAHATE values.

In addition, with the implementation of the program, the values to be achieved include: 1) togetherness; 2) Cooperation; 3) Family; 4) Professionalism; and 5) harmony will be fulfilled properly.

\section{SAHATE IMPACT}

The value of this local wisdom is one of the answers to the challenges of generations and times. Today's employees have a different character from Generation $\mathrm{X}$. With the development of technology and shifts in character; the millennial generation tends to be satisfied with the latest technology. the implementation of SAHATE in the Puslatbang environment has at least been able to reduce the individual level, as explained by the head of the Puslatbang administration unit, "This value encourages the new generation of employees to have more togetherness, especially at work."

Based on a statement from the head of the Human Resources Division of the
Puslatbang, the value of SAHATE local wisdom has a positive impact on changing the behavior of the apparatus, where each individual prioritizes collective interests in the agency, cares more about others and embraces employees who are a little more passive. A small example is when there is one employee who has obstacles in his work, which affects his performance. Other agencies will give several warnings to related employees regarding the performance. Still, the Puslatbang, with its local wisdom values, will embrace and encourage these employees to go through the entire process together.

SAHATE may not have an effect if it is applied in other areas outside of Sundanese culture, this is as explained by the Head of the Center for Research and Development, because SAHATE is absorbed from Sundanese cultural values and at the same time applied in West Java, where most of the employees are Sundanese. So its application has a positive impact on the work culture in the agency.

\section{CONCLUSION}

SAHATE is a philosophical value absorbed from the local Sundanese culture "Sarendeuk Saigel Sabobot Sapihanaeun, Sabata Sarimbagan," which means "always together, never fighting because of different opinions, getting along and respecting each other." In applying this philosophical value, there are various programs carried out by agencies to strengthen relationships between individuals to suppress individual and sectoral egos so that all employees or the State Civil Apparatus (ASN) can focus on organizational goals and not focus on individual or group interests. Therefore, to maximize the absorption of SAHATE values, the Human Resources section of the Jatinangor PKASN Puslatbang must be able to understand the purpose of the appointment of the SAHATE program as a guide in working and socializing and on time. 


\section{REFERENCES}

Anggara, S., Nur, M. I., \& Daroni, A. (2018). Implementasi Kebijakan Disiplin Pegawai Negeri Sipil Di Balai Latihan Kerja Mandiri Provinsi Jawa Barat. Publica: Jurnal Pemikiran Administrasi Negara, 10(1), 1-12. https://doi.org/10.15575/jpan.v10i1.7621

Ardiansyah, D. O. (2016). Pengaruh Komunikasi Terhadap Kinerja Karyawan Dengan Dimediasi Oleh Kerja. Jurnal Bisnis Dan Manajemen, 16-30.

Basheka, B. C. (2015). Indigenous Africa's Governance Architecture: A Need for African Public Administration Theory? Journal of Public Administration •, 50(3), 466-484.

Burford, G., Hoover, E., Velasco, I., Janoušková, S., Jimenez, A., Piggot, G., Podger, D., \& Harder, M. K. (2013). We are bringing the "Missing Pillar" into sustainable development goals: Towards intersubjective values-based indicators. Sustainability, 5(7), 3035-3059. https://doi.org/10.3390/su5073035

Cruz, P. D. La, Acosta, L. E., Mendoza, D., Baltazar, E. B., Arce Ibarra, A. M., \& Lugo, E. I. J. E. (2020). Indicators of well-being among indigenous peoples of the Colombian Amazon: Tensions between public policymaking and autonomy. Environmental and Sustainability Indicators, 7(March), 1-14. https://doi.org/10.1016/j.indic.2020.10004 4

Efendi, A. (2014). Implementasi Kearifan Budaya Lokal Pada Masyarakat Adat Kampung Kuta Sebagai Sumber Pembelajaran IPS. Sosio Didaktika, 1.

Hart, M. A. (2010). Indigenous Worldviews, Knowledge, and Research: The Development of an Indigenous Research Paradigm. Journal of Indigenous Voices in Social Work, 1(1), 116.

Hikmah, D. A., S, A. A. M., Utomo, A. P., Rozzaq, M., \& Rahmi, F. A. (2020). Local Indigeneous Governance dalam Meningkatkan Economic Growth di Kabupaten Siduarjo. Spirit Publik.

Jackley, M. . (2008). Testimony before the U.S. Senate Committee on Indian Affairs.

Johnson, J. T., Howitt, R., Cajete, G., Berkes, F., Louis, R. P., \& Kliskey, A. (2016). Weaving Indigenous and sustainability sciences to diversify our methods. Sustainability Science, 11(1),

1-11. https://doi.org/10.1007/s11625-015-0349$\mathrm{x}$

Jumiati, J., \& Saputra, B. (2019). Indigenous Public Administration: Public Administration Viewed from Local Wisdom Perspective. 320(Icskse 2018), 19-24. https://doi.org/10.2991/icskse-18.2019.3

Kementerian PAN-RB. (2018). Reformasi Birokrasi Kiprah Kementrian PAN-RB. 156.

Kementerian Pendayagunaan Aparatur Negara dan Reformasi Birokrasi. (2020). Tiga Elemen Reformasi Kelembagaan Pemerintah. Menpan.Go.Id.

https://www.menpan.go.id/site/beritaterkini/tiga-elemen-reformasi-kelembagaanpemerintah

Prasojo, E., \& Kurniawan, T. (2010). Good Governance dan Reformasi Birokrasi di Indonesia. Jurnal Penelitian Politik, 7(1), 121.

http://ejournal.politik.lipi.go.id/index.php/j pp/article/view/507/316

Riley, L., \& Johansen, M. (2019). Creating valuable indigenous learning environments. Journal of Public Affairs Education, 25(3), 387-411. https://doi.org/10.1080/15236803.2018.14 29815

Saputra, B., Suripto, \& Chrisdiana, Y. (2018). Indigeneous Public Administration: Melihat Administrasi Publik Dari Perstektif Kearifan Lokal (Local Wisdom). Jurnal Ilmu A, XV(2), 278-292.

Saputra, H., Syawaludin, Jamaludin, Saprudin, U., \& Tarwijo. (2020). Manajemen Pemerintahan Desa Dalam Mencapai Keunggulan Potensial Dan Berdaya Saing. Jurnal LOKABMAS Kreatif, 01(03), 81-86.

Tanyanyiwa, V. I., \& Chikwanha, M. (2011). The Role of Indigenous Knowledge Systems in the Management of Forest Resources. Journal of Sustainable Development in Africa, 13(3), 132-149.

theglobaleconomy.com. (2020). Government effectiveness in South East Asia. Theglobaleconomy.Com. https://www.theglobaleconomy.com/rankin gs/wb_government_effectiveness/SouthEast-Asia/

Zulfah. (2013). Peranan Sumber Daya Manusia Dalam Menghadapi Tantangan Era Globalisasi. 0(05). 